\title{
Conservation status of birds on Mindoro, Philippines
}

\author{
GUY C. L. DUTSON, TOM D. EVANS, THOMAS M. BROOKS, \\ DESIDERIO C. ASANE, ROBERT J. TIMMINS and ANGELA TOLEDO
}

\section{Summary}

Four weeks of fieldwork in the forests of Mindoro, Philippines, in 1991 has elucidated the status of the six bird species endemic to the island. Of these, Ducula mindorensis and Otus mindorensis are high-altitude species with restricted ranges and in need of active conservation in the medium term. Three of the four lowland species, Gallicolumba platenae, Centropus steerii and Penelopides mindorensis are under immediate threat of extinction through forest clearance and fragmentation, while the fourth, Dicaeum retrocinctum, is not under immediate threat but is certainly at risk of extinction in the long term. Whilst deforestation is an enormous problem across the entire Philippines, Mindoro is the smallest centre of endemism with the least forest cover after the Sulu Islands. Extinctions are believed inevitable within the next 10 years unless concerted action is urgently taken. The Halcon range must receive attention in order to conserve the montane species, but more urgent by far is the preservation of lowland forest remnants, concentrating on central-west Mindoro.

\section{Introduction}

Mindoro is one of the seven faunal provinces or centres of endemism in the Philippines, with six endemic bird species following the most recent taxonomic revisions (Dickinson et al. 1991 and other references in Scharringa and Inskipp 1991). It is the most poorly known of these faunal provinces, and has the least forest cover after the Sulu Islands, but the latter have just three endemic bird species. Whilst the attention of conservationists has, understandably, focused in recent years on the faunistically richer provinces of Luzon and Mindanao, which still have large tracts of forest in need of preservation, the threats of extinction to birds in the smaller faunal provinces are much more imminent. In this context, the status of forest birds on Mindoro has much in common with the faunal province of the Western Visayas, where the island of Negros was also surveyed in 1991 (Brooks et al. 1992). Satellite surveys in 1987 estimated the total forest cover on Mindoro as $8.5 \%$, of which about half was closedcanopy lowland and hill forest (Table 1 ). However, the remaining areas are

Table 1. Forest cover on Mindoro and the Philippines in 1987; areas in $\mathrm{km}^{2}$ (SSC 1988)

\begin{tabular}{lrrrrrr}
\hline $\begin{array}{l}\text { Forest } \\
\text { Type }\end{array}$ & $\begin{array}{l}\text { Closed } \\
\text { canopy }\end{array}$ & $\begin{array}{c}\text { Open } \\
\text { canopy }\end{array}$ & Mangrove & Mossy & $\begin{array}{r}\text { Total } \\
\text { forest }\end{array}$ & $\begin{array}{c}\text { Total land } \\
\text { area }\end{array}$ \\
\hline Mindoro & 203 & 501 & 27 & 140 & 871 & 10,196 \\
Philippines & 24,342 & 41,940 & 1,494 & 2,455 & 71,042 & 295,381 \\
\hline
\end{tabular}




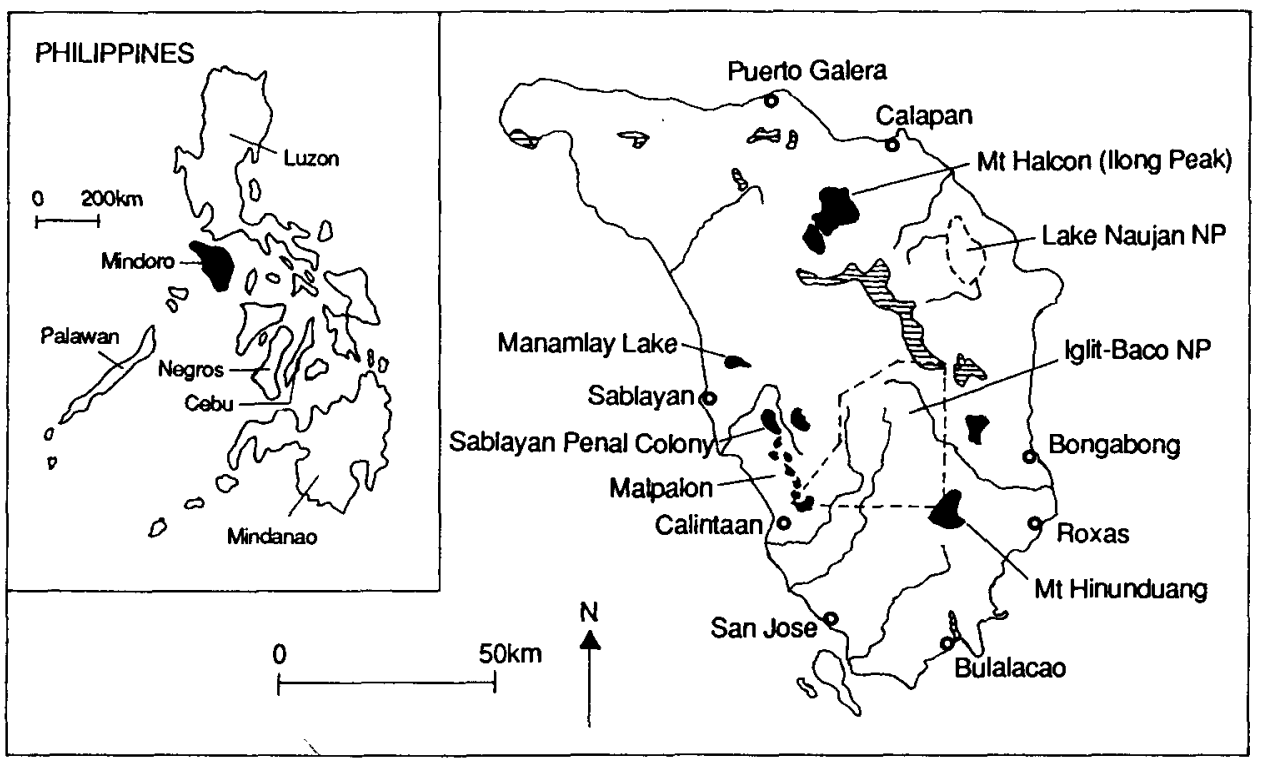

Figure 1. Map of Mindoro showing forest cover. Forest cover is based on maps produced by SSC (1988), modified according to the results of this survey. Shaded areas are those visited during fieldwork. Hatching indicates other forest areas shown on SSC (1988) but not visited by this survey. A dashed line indicates a national park boundary.

fragmented, include only tiny tracts of primary forest below $500 \mathrm{~m}$, and are in rapid retreat as human population pressure increases and infrastructure improves. Figure 1 indicates the distribution of remaining forest in 1987 (SSC 1988). However, ongoing small-scale clearance visible and reported since 1987 have reduced these worrying figures further.

\section{Historical collections on Mindoro}

Ornithological exploration of Mindoro has been geographically restricted to the north and east of the island. The commonest ecological information noted by these collections is the altitude of the site, for which a metre equivalent is given. The most thorough and recent collection was by the Yale Peabody MuseumSilliman University Mindoro Zoological Expedition in 1954 (Ripley and Rabor 1958). About 48 days were spent collecting in the lowlands to the east of the Halcon range at 8-60 $\mathrm{m}$ altitude (at Alcate, Victoria; San Luis, Naujan and Lake Naujan). In the Halcon range, 10 days were spent collecting at $760-1,460 \mathrm{~m}$ at Barawanan Peak, and 14 days at 910-1,980 $\mathrm{m}$ on Ilong Peak.

Other collections, listed in Dickinson et al. (1991), were mostly small and opportunistic in nature. Rather more thorough coverage was attained by Bourns and Worcester in 1891, Whitehead in 1895-1896 and McGregor in 1906, including a major ascent of the Halcon range by Whitehead (Ogilvie Grant 1896). All collections were centred around the north-east of the island except for a small 
collection by Porter around Bulalacao (Figure 1) which only recorded one Mindoro endemic: the Mindoro Tarictic Hornbill Penelopides mindorensis (McGregor 1906).

Recent collections in the highlands of Mindoro have been made by the National Museum of the Philippines but no results have been published. However, some information on the Mindoro endemics collected has been made available to us by P. Gonzales.

Mindoro was surveyed for endemic and threatened forest birds between 1 September and 2 October 1991 as part of the Cambridge Philippines Rainforest Project, a student expedition in conjunction with the Department of the Environment and Natural Resources (DENR) and the International Council for Bird Preservation (ICBP) in the Philippines (see Evans et al. in prep.) An effort was made to select the most important low-altitude forest remnants as identified from recent satellite maps (SSC 1988) and from discussion with local DENR officers. Six surveyors and a number of field assistants worked at each site. One of us (R.J.T.) returned to survey further sites between 14 and 29 December 1991.

\section{Species accounts of birds endemic to Mindoro}

\section{Mindoro Bleeding-heart Gallicolumba platenae}

Historical status This species was taken by many of the early collectors between $12^{\circ} 52^{\prime}-13^{\circ} 23^{\prime} \mathrm{N}$ and $120^{\circ} 52^{\prime}-121^{\circ} 18^{\prime} \mathrm{E}$. Ripley and Rabor (1958) noted it as not really rare, but very local, preferring a rather dry type of forest floor especially on a gentle gradient in both primary and secondary forest. They took three birds at $30 \mathrm{~m}$ at San Luis and one at $60 \mathrm{~m}$ at Alcate.

Expedition records Ground-doves of the genus Gallicolumba are notoriously difficult to observe in the field. The paucity of records of these species should be compared with a similar incidence on Negros (Brooks et al. 1992) but contrasted against an apparent relative abundance on Luzon (various unpublished birding records: T. H. Fisher verbally 1991). Only one Common Emerald-dove Chalcophaps indica was seen on Mindoro; this species prefers secondary forest at fairly low altitude (pers. obs.), but nonetheless was seen surprisingly infrequently on Mindoro. Mist-netting on Mindoro was only carried out for a short period and caught no terrestrial columbids. A few columbids were flushed from the ground, including one bird together with a White-eared Brown-dove Phapitreron leucotis, the latter perching sufficiently long for identification and indicating the need for extreme caution when identifying flush records.

At Sablayan, the largest tract of lowland forest known on Mindoro, two single G. platenae were seen on the ground on 23 December. The first bird was in an open area of the forest floor under closed-canopy forest bounded by limestone outcrops and boulders. The second bird walked to within $4 \mathrm{~m}$ of the observer in a bamboo thicket with numerous rattans, surrounded by primary closed-canopy forest. Both birds soon walked out of sight into thick undergrowth. This habitat was much the same as that in which Luzon Bleeding-hearts G. luzonica were seen on Mt Makiling, Luzon (pers. obs.). 
G. platenae was reported by local villagers at San Vicente and Malpalon. The Kalikasan Mindoro Foundation has reports of the species being relatively common in the far south of Mindoro some years ago (per L. Gabutero verbally 1991). About $5 \mathrm{~km}$ of forest was seen from the sea on a ferry journey around the south-east coast between Bulalacao and San Jose. There is still a significant area under forest, but most of it has been opened up by patches of cultivation and logging and nothing showed up on the 1987 satellite maps (SSC 1988).

Much of the forest on Mindoro has large numbers of snares set for terrestrial animals; two paths in different forests at Malpalon were flanked by a continuous line of snares, totalling several hundred metres. G. platenae is likely to be susceptible to these traps and indeed to be targeted for meat and the pet trade. Although we had no evidence of captive $G$. platenae, the commoner $G$. luzonica is widely offered for sale. Sixteen G. luzonica were seen in Cartimar Market, Manila, on 1 December 1991 and one in a private collection in Cebu (pers. obs.). The scarcity of recent records from hunters in the forests visited suggests that numbers of $G$. platenae are low.

Other recent records、 None.

Present status A combination of apparent low population density, hunting pressure and rapid destruction of lowland forest on Mindoro makes this species highly threatened. Red Data Book status is likely to be Endangered.

\section{Mindoro Imperial-pigeon Ducula mindorensis}

Historical status This species was taken by only one of the early collectors: Whitehead recorded it between 1,220 $\mathrm{m}$ and $1,830 \mathrm{~m}$ on Mt Dulungan (part of the Halcon range), singly or in pairs, but occasionally up to four together (Whitehead 1899). Its scarcity is illustrated by Whitehead's comment that it was "most difficult to obtain, and in nearly four months I only secured five specimens" (Ogilvie Grant 1896). Ripley and Rabor (1958) saw and heard the bird several times around Barawanan Peak at about $1,460 \mathrm{~m}$ but failed to secure any specimens.

Expedition records This pigeon was not uncommon at the Mt Ilong survey site where a total of 15 birds were seen and seven heard in six days. Further birds were likely to have been overlooked because of the difficulty of identifying individuals flushed from within forest. However, most records were from the lowest-altitude forest remaining at the site, between $800 \mathrm{~m}$ and $950 \mathrm{~m}$; there was only one record from the relatively large area of primary forest above $1,050 \mathrm{~m}$, and one more in closed forest beyond llong Ridge at 1,500 m. Mountaineers in Calapan reported seeing this species in mossy forest at 2,000 $\mathrm{m}$ on Mt Halcon.

Three birds were heard in tall mid-mountain forest on steep terrain at 7oo$750 \mathrm{~m}$ at San Vicente. Pigeon activity was low there, with for instance only one Pink-bellied Imperial-pigeon $D$. poliocephala heard, perhaps in part because of the poor weather, so that $D$. mindorensis may have been commoner. This site is about $8 \mathrm{o} \mathrm{km}$ south of all previous published records, which have been from the 
Halcon range. The species was not recorded from the Malpalon district and no definite records were known to the Kalikasan Mindoro Foundation.

No actual evidence of hunting was obtained but hunters throughout the Philippines shoot imperial-pigeons because of their size, so $D$. mindorensis is presumably under threat from any increase in hunting at this altitude.

The disyllablic call was clearly that of a Ducula imperial-pigeon, but much deeper and more resonating than calls heard from congeners. It is possible that similar calls are uttered by other species on Mindoro, but all records were treated as $D$. mindorensis (a) in the absence of any evidence that other species sound the same, (b) from the lack of any such calls on Negros where Pink-bellied Imperial-pigeon $D$. poliocephala was fairly common (pers. obs.), and (c) since just this one call was heard from $D$. mindorensis. This call was only heard seven times at Halcon, whereas the call of $D$. poliocephala was heard eight times compared to just one sighting of the latter species. This may indicate a difference in the calling rate of these species or a preference for understorey and hence greater observability of $D$. mindorensis.

Birds were usually encountered in understorey trees (perhaps because of their unobtrusiveness when in the canopy). Two were watched feeding about $50 \mathrm{~m}$ apart from each other, the one bird calling intermittently. Both were the only birds feeding on the small fruits of two unidentified trees. One other bird was seen at roost in the top of a tall tree in a clearing on the lower edge of closed forest. Up to 15 large pigeons were seen flying into this roost at dusk each day, but the few that could be identified indicated a mixed-species assemblage (one D. mindorensis, one D. poliocephala, one Metallic Pigeon Columba vitiensis). Two birds were seen close enough to detail the bare part coloration, which included deep red orbital skin, given by Goodwin (1983) as indicating male birds.

Other record records One was reported by $\mathrm{R}$. Sison (per R. S. Kennedy in Collar and Andrew 1988) in the lowlands of north-east Mindoro. This record seems most surprising since there are no historical records from lowland and no forest whatsoever was visible in north-east Mindoro from viewpoints on Ilong Ridge in 1991 (the entire width of coastal plain from Puerto Galera to Lake Naujan was examined through binoculars in good light).

King reported the species as common on Halcon in 1983 (Collar and Andrew 1988); however, this evidence was based on just one bird seen over four days, when the relevant aspect of Halcon was reported to be forested down to $500 \mathrm{~m}$ (B. F. King in litt. 1991).

Birds were taken in the highlands on Mount Halcon and Iglit-Baco National Park by the National Museum (P. Gonzales verbally 1991).

Present status It seems likely that the species is distributed throughout the mountains of Mindoro where sufficient forest remains in its altitudinal range. Although these are high-altitude and at less risk from clearance, logging is continuing to reduce suitable habitat at Halcon and San Vicente. Considering the low population density and extensive area of forest needed, which would be even greater if this species, like many other large frugivores, is nomadic in times of fruit scarcity, the species is best considered still threatened, probably with the Red Data Book status of Vulnerable. 


\section{Black-hooded Coucal Centropus steerii}

Historical status Recorded by many of the early collectors. Although these references contain minimal ecological data, the large number of specimens of this unobtrusive species indicates that it must have been relatively common and widespread. Both Ogilvie Grant (1896) and Whitehead (1899) reported it as restricted to low-altitude forest, where it inhabits treetops (unlike the Philippine Coucal C. viridis).

Ripley and Rabor (1958) recorded the species as fairly common in lowland Dipterocarp forest, with occasional records up to $760 \mathrm{~m}$ on Barawanan Peak where the forest was transitional Dipterocarp-mid-mountain forest; eight specimens were taken in the lowland sites at $30-60 \mathrm{~m}$. The species was noted to occupy the same ecological niche as the Black-faced Coucal C. melanops in the southern Philippines. A similar number of $C$. viridis were taken at the lowland sites, penetrating primary forest as far as the edges of clearings in high forest, but none was recorded from the highlands.

Expedition records Two birds were heard calling and one was seen on 1 October at about $430 \mathrm{~m}$ altitude at the Malpalon survey site. The call was quite distinct from any other calls heard during the expedition. It was intermediate in general quality between a coucal and an imperial-pigeon Ducula. Usually three notes were given, although up to five notes were commonly uttered and six notes once. Each note was a deep boom of about 0.5 second duration, with a 0.25 second pause between each. Two birds, about $50 \mathrm{~m}$ apart, were recorded calling continuously at each other alternately, with an average of 20 seconds between calling bouts. Calling was discontinued by one bird spontaneously and by the other bird when disturbed by the observer.

Explosive coucal calls, transcribed as "tchoc-cou" were heard from the same area 10 minutes earlier and were most probably from the same birds. This call appeared indistinguishable from similar calls given by both Philippine Coucal and Lesser Coucal C. bengalensis. No long series of deep booming notes as given by many other coucal species, including the two above species on Mindoro, was heard.

The birds were in a small $600 \mathrm{~m}$ wide tract of primary forest extending downhill from a very rocky ridge. The terrain was broken and rocky with occasional boulders up to $5 \mathrm{~m}$ high. The rough terrain appeared to be the reason for this tract of forest remaining uncleared amongst cultivation encroaching as close as $200 \mathrm{~m}$ from the birds. The substrate caused the forest to be extremely broken with many sunny openings and a heavy infestation with bamboos and creepers. Scattered big trees reached $30 \mathrm{~m}$ height and cast deep shade over areas relatively free of undergrowth in small patches, giving a very heterogeneous forest structure overall.

Two singles were seen at Sablayan on 22 December; one called briefly as described above. Their behaviour of running along branches, preferring thick tangles of climbing plants, reluctance to fly and shy yet inquisitive nature was reminiscent of other species of coucal, especially the other forest congeners in the Philippines, Rufous C. unirufus and Black-faced Coucals. However, the latter two species generally associate with conspecifics or other birds (pers. obs.). 
Both birds were seen between 5 and $15 \mathrm{~m}$ above the ground. The first was well inside closed-canopy forest, the second in a strip of recent secondary forest bordering closed-canopy forest.

No C. steerii were recorded elsewhere. At Halcon, C. viridis, a species known to occur in secondary but not primary forest, was recorded up to $1,000 \mathrm{~m}$ in selectively logged forest with areas of bushy regrowth. No $C$. viridis were taken on Halcon by Ripley and Rabor (1958). At San Vicente, unidentified coucal calls were heard at a number of sites up to $600 \mathrm{~m}$ altitude. These calls were of the non-specific "tchoc-cou" types and long series of booms, the latter very similar to that of $C$. viridis. Many were recorded from primary forest but were either close to the river or to small plantations of banana or coconut within the forest. It was concluded that these coucals were likely all to have been $C$. viridis, which is thought to displace $C$. steerii in degraded forest (Collar and Andrew 1988).

The plumage of $C$. steerii is not as distinctive as might be assumed from DuPont (1971). The contrast between the black head and throat and brown body was not always visible, but the head is not glossy (unlike $C$. viridis) and may appear shaggy. It should be noted that $C$. viridis on Mindoro is a very distinct subspecies C. $v$. mindorensis, which closely resembles $C$. steerii in having black wings (all other subspecies except from the Batanes Islands have rufous wings).

\section{Other recent records None.}

Present status It would appear from the expedition records that this species is dependent on lowland forest with minimal secondary bush infiltration. Such forest on Mindoro is fragmented, mostly in very small tracts, and is likely all to be cleared in the next 10 or 20 years. Status: Endangered.

\section{Mindoro Mountain Scops-owl Otus mindorensis}

Historical status The species was taken only by Whitehead in the Halcon range (Ogilvie Grant 1896).

Expedition records The bird appeared to be common above 1,050 $\mathrm{m}$ in closed forest. At Mt Ilong, none was heard below an abrupt vegetational change into montane forest at $1,050 \mathrm{~m}$. Above this, a maximum of nine were heard from $1.5 \mathrm{~km}$ of path bisecting a plateau with homogeneous montane forest. This reached $1,320 \mathrm{~m}$ and the path continued through forest interspersed with patches of bamboo and land-slip, between 1,300 and 1,450 m. Only one owl was heard in $5 \mathrm{~km}$ of the latter habitat surveyed at night.

At San Vicente, there was no abrupt change into montane forest and the paths only reached $990 \mathrm{~m}$ altitude. However, one bird was heard at $870 \mathrm{~m}$ in four hours of surveying the highest-altitude paths after dark. This appears to be the only record ever away from the Halcon range. The bird was not recorded elsewhere in Mindoro but no other forest above $750 \mathrm{~m}$ was surveyed.

All records were of birds calling after dark. Considering the similarity in counts of 6, 9 and $6+$ on three nocturnal walks of the $1.5 \mathrm{~km}$ path, it was considered that a high proportion of the individuals were calling and presum- 
ably territorial. No other owls were heard so frequently elsewhere in the Philippines, and although seasonality of calling may be significant, Otus mindorensis did appear to be at an exceptionally high density along the path. The call was a single-note whistling hoot, similar in tune to Tawny Owl Strix aluco but shorter, with little resonance and no quaver, and higher-pitched such that an accurate imitation by the observer was possible by whistling. Each note was about 1.5 seconds long with a variable interval of at least 5 seconds between notes. Recordings of the call were made. Birds called spontaneously for variable and intermittent periods but responded to imitation by flying in close, calling and changing tree frequently. Birds perched at about $8 \mathrm{~m}$ up in $12 \mathrm{~m}$ tall trees, never perching in bamboo. No eyeshine was elicited with either a head-lamp or a spot-light and only flight-views were obtained.

Other recent records B. F. King reported the species as common on Mount Halcon in 1983 (Collar and Andrew 1988), recording the species in unknown numbers on each of the days spent on the mountain (B. F. King in litt. 1991). Birds were taken in the highlands on Mount Halcon and Iglit-Baco National Park by the National Museum (P. Gonzales verbally 1991).

Present status This species was recorded at a surprisingly high density at Halcon. The San Vicente record suggests that, like the Mindoro Imperialpigeon, it is probably found throughout the mountains of central Mindoro. Forest at this altitude is likely to survive in small patches. However, the small and slowly shrinking area that it is restricted to indicates a Red Data Book status of Rare.

Scops-owls in the lowlands of Mindoro O. mindorensis is the only known scops-owl on Mindoro. However, another species exists, distinguishable by its call, lowland distribution and possibly plumage. These were heard frequently at Malpalon and Sablayan and are well known by the local people who report it as common and tolerant of very degraded forest including farmland. The call is a rolling trill of a few seconds duration, repeated at fairly regular short intervals. Two were seen in daytime at Sablayan. These had a plain face pattern except for prominent creamy eyebrows which did not meet in the midline. The face was slightly paler brown than the crown and the irides dark yellow. The underparts were buff with fine neat darker bars. The upperparts were not well seen but were darker brown, possibly barred, with a creamy-buff leading edge to the closed wing from the carpal to about halfway down the wing. This may be one of a number of species of scops-owl on adjacent islands or a new species. Its absence from historical collections may indicate a restriction to the drier west side of Mindoro, which has never been worked by collectors.

\section{Mindoro Tarictic Hornbill Penelopides mindorensis}

Taxonomic status This taxon has long been regarded as a subspecies of the Tarictic Hornbill Penelopides panini, a species widespread in the Philippines. However, Kemp (1988), in the most recent and thorough review of hornbills, 
proposes that $P$. panini should be split into four species, including $P$. mindorensis as a Mindoro endemic. Sibley and Monroe (1990) go even further, recognizing five species within the superspecies. No studies of the ecology, behaviour or vocalizations of these species have been conducted. However, the call of $P$. mindorensis is much deeper and less trumpet-like than Visayan Tarictic Hornbill $P$. panini.

Historical status The species was widely taken by the early collectors and was the only Mindoro endemic taken by Porter in the south-east of the island (McGregor 1906). Ripley and Rabor (1958) recorded the species as fairly common in primary forest, forest edge, sometimes in secondary growth and occasionally in isolated fruiting trees in cultivated areas. Six specimens were taken in the lowlands and it was seen rarely up to $1,070 \mathrm{~m}$.

Expedition records Hornbills were only recorded in the lowland sites in west Mindoro, although local villagers reported them from San Vicente. Birds may well occur at San Vicente at similarly low densities to those recorded in midmountain forest on Negros (Brooks et al. 1992) but went undetected because of the small amount of time available for field observations at this site.

At Malpalon, P. mindorensis was recorded in pairs on four occasions in September and twice in December, with a single female in December, indicating a reasonably high population density (or observability) in comparison to the other sites on Mindoro and the encounter rate with Negros Tarictic Hornbill P. (p.) panini. Birds were seen daily within or on the edge of the patchy primary forest at $400-750 \mathrm{~m}$ at Malpalon. A pair were seen in a narrow streamside patch of forest some $4 \mathrm{~km}$ to the south; this forest was separated from the nearest large tract of high forest by about $400 \mathrm{~m}$ of cultivation. Birds were observed feeding twice. Once, a pair were repeatedly flushed from lower and middle storeys within forest, and once a pair were foraging for at least an hour throughout the foliage of a large isolated forest-edge tree. At Manamlay Lake, a group of at least four birds were seen on the first day and heard on the second. Daily records at Sablayan included a group of at least four, three singles, and two groups which were heard only.

Other record records Members of the Kalikasan Mindoro Foundation saw the species elsewhere in the Malpalon district, well away from closed forest, in 1991 (L. Gabutero verbally 1991). Birds were taken in north-west Mindoro by the National Museum (P. Gonzales verbally 1991).

Present status P. mindorensis appears to feed extensively in forest edge and tiny forest patches. However, it may still be dependent for food or nest-sites on larger tracts of closed forest, and does appear to be very restricted by altitude. Its population density is likely to be low; the highest density of any species of Oriental forest hornbill in a large study in Malaysia was just over two groups per $\mathrm{km}^{2}$ of pristine forest (Johns 1988). As such, this species should be given a Red Data Book status of Vulnerable or Endangered. 
Scarlet-collared Flowerpecker Dicaeum retrocinctum

Historical status Birds were taken in a number of sites between $12^{\circ} 50^{\prime}-13^{\circ} 23^{\prime} \mathrm{N}$ and $120^{\circ} 52^{\prime}-121^{\circ} 23^{\prime}$ E. Ripley and Rabor (1958) apparently only recorded this species in the lowlands, where it was rather common. Usually found in primary forest, it was also occasionally seen in well-cultivated areas, especially coconut groves. Rabor also noted the similarity in ecology to the Negros (sub)species of Red-keeled (= Philippine) Flowerpecker D. (australe) haematostictum.

Expedition records This species was a common component of mixed-species flocks at all sites except for Malpalon in September, when none was seen.

At Halcon, it was one of the commonest species in closed forest, with a total of 44 bird-days, despite its canopy habits causing it to be greatly overlooked. This abundance compares with 29 bird-days for Bicoloured Flowerpecker $D$. bicolor (and one Pygmy Flowerpecker D. pygmaeum and one Orange-bellied Flowerpecker D. trigonostigma bird-day). Although common in the lower forest between 800 and $1,050 \mathrm{~m}$, it was only once recorded in montane forest above this altitude, at $1,200 \mathrm{~m}$. At San Vicente, birds were seen relatively more often; a total of 31 bird-days were recorded. Birds were seen only above $550 \mathrm{~m}$ at this site, despite degraded forest extending down to $150 \mathrm{~m}$. Although this may in part have reflected the relative lack of observation at lower altitudes, several hours of observation were made along the river and $D$. retrocinctum must be present at much lower population densities if it occurs there at all. Perhaps there is a degree of nomadism in the species since none was seen in September at Malpalon despite numerous $D$. bicolor and a few D. pygmaeum being noted. In December six $D$. retrocinctum were observed at Malpalon (with four $D$. bicolor and one Striped Flowerpecker D. aeruginosum); at Manamlay Lakes one was seen, and three were found at Sablayan.

In closed forest, it was most often seen in ones and twos in mixed-species foraging flocks, gleaning high in the canopy or occasionally visiting epiphytic flowers. In forest edge and logged forest it was also common and observations were easier. Birds here had a very similar foraging ecology to $D$. bicolor, active within the entire vegetated portions of canopy trees but rarely descending to bushes. In December, however, more birds were seen at lower canopy levels, including higher understorey vegetation.

One common call was similar to that of Red-keeled (= Philippine) Flowerpecker $D$. australe and hence easily distinguishable from Bicoloured Flowerpecker, the only other common congener on Mindoro, although another call appeared indistinguishable. Its plumage similarity to $D$. australe and the possibly distinct species $D$. (a.) haematostictum (see Brooks et al. 1992) is quite obvious in adults and more so in juveniles. Juveniles of all three allospecies are probably indistinguishable in the field: uniform dull grey-brown above and paler dirty grey below with a moderately long decurved bill with a pale base to the lower mandible.

Other recent records Recorded on just one day out of four spent on Mt Halcon in 1983 by B. F. King (in litt. 1991). Birds were taken at a number of sites by the National Museum (P. Gonzales verbally 1991). 
Present status This species is present at high population densities over a wide altitudinal range, although it appears to be poorly tolerant of highly degraded forest. Deforestation on Mindoro is likely to continue reaching all its altitudes and to leave little secondary forest. Its treatment as only "near-threatened" in Collar and Andrew (1988) is presumably based in part on the species's claimed tolerance of poor habitat (e.g. Ripley and Rabor 1958). However, it is perhaps best regarded as threatened with Red Data Book status of Vulnerable.

\section{Other threatened taxa recorded from Mindoro}

\section{Subspecies endemic to Mindoro}

Although conservation interest is largely focused on forms regarded as species, subspecies also contribute significantly to biodiversity. The degree of subspecific distinctiveness is clearly very variable from minor to quite major. In the following list of all the Mindoro single-island endemic subspecies, those under potential threat of extinction are identified with an approximate Red Data Book status:

Blue-crowned Racquet-tailed Parrot Prioniturus discurus
mindorensis

Philippine Hanging-parrot Loriculus philippensis mindorensis Philippine Coucal Centropus viridis mindorensis

Philippine Hawk-owl Ninox philippensis mindorensis

White-bellied Woodpecker Dryocopus javensis mindorensis Black-bibbed Cicadabird Coracina mindanensis elusa

Philippine Bulbul Hypsipetes philippinus mindorensis White-browed Shortwing Brachypteryx montana mindorensis Island Thrush Turdus poliocephalus mindorensis Tawny Grassbird Megalurus timorensis mindorensis Mangrove Blue Flycatcher Cyornis rufigastra mindorensis

Green-backed Whistler Pachycephala plateni mindorensis Mountain Shrike Lanius validirostris tertius Golden-yellow White-eye Zosterops nigrorum mindorensis Mountain White-eye $Z$. montanus halconensis threatened (?Vulnerable) near-threatened not threatened threatened (?Endangered) not threatened threatened (?Endangered) not threatened not threatened not threatened not threatened threatened (?Vulnerable) near-threatened near-threatened not threatened not threatened

The classifications above as "threatened" or "near-threatened" are based on the ability of the subspecies (or the species if there are insufficient data from Mindoro) to tolerate degraded forest and on restriction to lowland forest. The Blue-crowned Racquet-tailed Parrot is discussed in the next section. The Philippine Hawk-owl has not been recorded on Mindoro since 1954, when it was only found in the lowlands (Ripley and Rabor 1958). This species is not uncommon on other islands (various unpublished birding reports) but surveys are urgently needed in the calling season on Mindoro. The Black-bibbed Cicadabird has been recently proposed as a species endemic to the Philippines excluding Palawan (White and Bruce 1986, Scharringa and Inskipp 1991). It was reported by Ripley 
and Rabor (1958) to be not common in lowland forest on Mindoro. The only recent field records of this species anywhere (other than our own) have been from a handful of lowland forest sites in Luzon and Mindanao and the species may well be in danger of global extinction (T. H. Fisher verbally 1991).

One species treated as "near-threatened" above but not restricted to lowland forest is the Mountain Shrike. This bird is found uncommonly in open and broken forest above 1,000 $\mathrm{m}$ on Luzon and Mindanao (e.g. Dickinson et al. 1991). There are only two previous records from Mindoro: taken by Whitehead at $1,520 \mathrm{~m}$ on Mt Dulungan (Whitehead 1899) and by the National Museum on Mount Halcon (P. Gonzales verbally 1991). Three birds were recorded at San Vicente in forest between 500 and $870 \mathrm{~m}$, two in small patches of secondary growth surrounded by primary forest, the other well within primary forest. It should be noted that although the migrant Brown Shrike Lanius cristatus is considered an open-country species, it became frequent in closed forest at San Vicente during the fieldwork.

\section{Other threatened and near-threatened species as proposed by Collar and Andrew (1988)}

At least one adult and one juvenile Philippine Hawk-eagle Spizaetus philippensis (near-threatened) were seen at Sablayan; the species was not recorded by Ripley and Rabor (1958). Although unobtrusive and easily overlooked, it is clearly threatened on Mindoro and Negros (Brooks et al. 1992) and presumably on other such deforested islands.

Tabon Scrubfowl Megapodius cumingii (near-threatened) was not recorded during our fieldwork, although the Kalikasan Mindoro Foundation has a number of largely unsubstantiated reports (per L. Gabutero verbally 1991). As with the previous species, it is threatened on the islands visited by the expedition.

Spotted Imperial-pigeon Ducula carola (near-threatened) was similarly unrecorded on Mindoro or Negros, although it is reported from Malpalon (S. Tejada verbally 1991).

One Philippine Cockatoo Cacatua haematuropygia (threatened) was seen by one of our co-workers at Malpalon (E. Tejada verbally 1991). This species is reported to persist as scattered pairs at all the sites visited but usually only seen when raiding crops with other parrot species. Trapping for the pet trade is so intense throughout its range that it is in danger of becoming extinct in the near future (Lambert 1992). From the reports of local people it seemed to be more commonly seen in the Malpalon area than at other of our survey sites.

Blue-crowned Racquet-tailed Parrot Prioniturus discurus (near-threatened) was common and conspicuous at all three sites, occurring up to at least $1,200 \mathrm{~m}$. Ripley and Rabor (1958) recorded it up to $1,670 \mathrm{~m}$, above the altitude surveyed in 1991. If its abundance and altitudinal range elsewhere in its extensive Philippines range is similar to that on Mindoro, it should be in no imminent danger unless a market for captured birds appears.

Blue-naped Parrot Tanygnathus lucionensis (not threatened) was not mentioned in Collar and Andrew (1988), but the dearth of recent records anywhere outside Palawan (e.g. T. H. Fisher verbally 1991, Brooks et al. 1992) indicates treatment as threatened. It appeared to be common in lowland forest in 1954, when Ripley and Rabor (1958) took 13 specimens, all below $60 \mathrm{~m}$. Two singles were seen at 
Sablayan, both in cultivated areas close to closed-canopy forest, and the species was reported at Malpalon where a pet, trapped many years ago, was seen. Although not usually treated as endemic to the Philippines (e.g. Dickinson et al. 1991), it is found elsewhere only on a handful of small islands between the Philippines and Borneo and Sulawesi.

One Ashy Ground-thrush Zoothera cinerea (near-threatened) was mist-netted at $800 \mathrm{~m}$ at San Vicente. There appear to be just two previous records of the species on Mindoro (Bourns and Worcester 1894, McGregor 1905, 1906). Elsewhere it is found on Luzon, where it is probably not uncommon in lowland forest (e.g. McClure and Leelavit 1972). Although far more extensive on Luzon $\left(7,621 \mathrm{~km}^{2}\right.$ closed-canopy and $16,034 \mathrm{~km}^{2}$ open-canopy Dipterocarp forest in 1987: SSC 1988), this is still a highly threatened habitat.

Rufous Paradise-flycatcher Terpsiphone cinnamomea (near-threatened) is probably a lowland forest specialist occurring at low population densities; two singles were seen at Malpalon. Although presumably very rare on Mindoro, the species is widespread, if scarce and threatened, throughout the Philippines.

\section{Status of other lowland forest birds}

A number of other lowland forest birds were not recorded during the 1991 fieldwork. Although some, such as the Black-chinned Fruit-dove Ptilinopus leclancheri, are likely to have been under-recorded because of unobtrusive and/or shy habits, many were taken quite commonly in the lowlands by Ripley and Rabor (1958). These are not presently globally threatened species but are good indicators of how little lowland forest remains on Mindoro. All the forest species known from Mindoro but unrecorded in 1991 (Appendix) are lowland specialists with the exception of some of the raptors (which occur at low population densities, so are likely to have been overlooked), Philippine Swiftlet Collocalia mearnsi (which is dubiously identifiable in the field), Sunda Ground-thrush Zoothera andromedae and Tawny-breasted Parrotfinch Erythrura hyperythra (both overlooked in the highlands).

\section{Mammals on Mindoro}

Mindoro, in common with the Philippines as a whole, has very few species of large mammal but a wide range of rodent and bat species. Details of the mammals recorded on Mindoro in 1991 will be available in Evans et al. (in prep.). The large mammals include the tamaraw Bubalus mindorensis, a single-island endemic bovid, considered endangered by IUCN. The management plan for this species (Cox and Woodford 1990) is relevant to the conservation of Iglit-Baco National Park and conservation in general on Mindoro.

\section{Status of forest habitat on Mindoro}

\section{Sites surveyed in 1991}

The difficulties of locating and reaching forest limited the time spent in the field to the dates shown in Table 2. In addition, incessant rain at both San Vicente 
Table 2. Effort at the sites

\begin{tabular}{|c|c|c|c|c|}
\hline Dates & Site & $\begin{array}{l}\text { Man-hours } \\
\text { in forest }\end{array}$ & $\begin{array}{l}\text { Mist-netting } \\
\text { (metre-hours) }\end{array}$ & $\begin{array}{l}\text { Night-torching } \\
\text { (hours) }\end{array}$ \\
\hline o4 Sep-1o Sep & Mt Ilong & 141 & 163 & 12 \\
\hline 13 Sep-20 Sep & San Vicente & 95 & 2,312 & 4 \\
\hline 24 Sep-o1 Oct & Malpalon & 28 & 90 & o \\
\hline 14 Dec-17 Dec & Malpalon & 22 & o & o \\
\hline $20 \mathrm{Dec}-21 \mathrm{Dec}$ & Manamlay Lake & 10 & 0 & o \\
\hline $22 \mathrm{Dec}-24 \mathrm{Dec}$ & Sablayan Penal Colony & 18 & 0 & o \\
\hline
\end{tabular}

'This figure is given as a gauge of effort at each site, to be used in conjunction with the Appendix. The unit taken is time spent in forest (including patches of forest and open forest at Malpalon), with more than one observer working together counting as a single observer.

and Malpalon greatly reduced time out of camp, whilst the severe recent deforestation at the latter caused much abortive hiking in search of forest.

\section{Mt Ilong}

Location Mt Ilong, barangays Magtibay and Paitan, Calintaan municipality. Part of the Mt Halcon range.

Forest description Forest was fairly extensive in patches on the Halcon range, although very large areas had been cleared and kaingin (shifting cultivation) was penetrating far up the more accessible valleys. In the area visited, the lower edge of the forest was around $750 \mathrm{~m}$. It descended somewhat lower on ridges and valley sides to the north and south, but was broken-canopied there. Between 750 and $850 \mathrm{~m}$, logging by pit-saw was intensive and the forest very open, with trees up to $20 \mathrm{~m}$ tall and a dense scrub layer. Only above $850 \mathrm{~m}$ did natural primary forest of the lowland/mid-mountain transition type exist, extending up to $1,000 \mathrm{~m}$ with a canopy around $15 \mathrm{~m}$. There was a sharp change in relief at $1,050 \mathrm{~m}$ leading onto the gentler slopes between here and Ilong Ridge $(1,310-1,440 \mathrm{~m})$. Forest on this plateau was stunted (only around $10-12 \mathrm{~m}$ tall) with a highly uneven canopy and many needle-leaved trees. Beyond llong Peak, the forest reverted to a montane type, with large areas of bamboo thicket and landslides with herbaceous cover between 1,000 and about $1,700 \mathrm{~m}$, over a cultivated valley bottom.

Human use Pit-saw logging had severely damaged the forest below $850 \mathrm{~m}$. Kaingin encroachment was occurring close behind this logging. Rattan, canes and vines were harvested; parrots were also collected (although those offered had been caught specifically for sale to us). A Catholic church mission in the hills must have been sizeable, judging by the daily passage of people walking $15 \mathrm{~km}$ through the forest to it. Mt Halcon is a regular mountaineering destination in the dry season.

Conservation status There was a DENR sustainable-use project (i.e. secondary forest underplanted extensively with rattan for harvest) in an adjacent valley 
and reforestation sites in more distant parts of the massif, but the bulk of the area is difficult of access and hence unpatrolled. The catchments appear extremely vulnerable to erosion, judging from the number of visible landslides.

Birds of particular conservation interest Mindoro Imperial-pigeon, Mindoro Mountain Scops-owl, Scarlet-collared Flowerpecker, with Philippine Cockatoo reported.

\section{San Vicente}

Location Watershed of Tauga River below Mt Hinungunang, barangay San Vicente, near Roxas.

Forest description The fieldwork concentrated on the lowest-altitude quality forest and the mountain itself was not visited. No primary forest was found below $550 \mathrm{~m}$ although the long valley of the Tauga River, which provides access, had large trees and scattered secondary forest along its sides and floor down to about $150 \mathrm{~m}$. Kaingin and small plantations (of fruit and cash crops) had penetrated most of the valley bottoms up to 500 or $600 \mathrm{~m}$ and were scattered through the remaining forest. The forest was of true lowland type at its lowest altitudes, but higher up was impoverished by steep slopes, exposure and recent logging (an abandoned road crosses the area at $750-820 \mathrm{~m}$ ) and was therefore difficult to assign to type. Small blocks of closed-canopy primary lowland forest persisted on some flatter ridges.

Human use Kaingin and plantations were encroaching as detailed above. The forest was used for rattan and creeper harvesting, and hunting of birds and pigs.

Conservation status Zoned by the local DENR for reforestation, timber stand improvement and rattan plantation by concession holders. DENR had plantation sites much lower down the river which are not yet mature enough to take pressure off the natural forest.

Birds of particular conservation interest Mindoro Imperial-pigeon, Mindoro Mountain Scops-owl and Scarlet-collared Flowerpecker, with reports of Mindoro Bleeding-heart, Philippine Cockatoo and Mindoro Tarictic Hornbill.

\section{Malpalon}

Location Forest remnants in the upper portions of barangays Malpalon, Marpalon, Lagutay and Balani, in Calintaan and Sablayan municipalities. These barangays all abut on a forested limestone ridge just outside Iglit-Baco National Park.

Forest description Clearance had been very recent here, such that many big trees and residual patches of forest exist in the lowlands, especially along field edges and watercourses. Continuous forest is now only found on steep ridgeside land. Here the forest was on very irregular broken ground, creating 
heterogeneous forest types with many areas of scrubby thickets and few tracts of tall shady forest. The ridge peaked at over $1,000 \mathrm{~m}$, and was forested for several kilometres.

Human use Extensive clearance for kaingin. Forest fires, spreading from areas of secondary growth and cogon (grassland), can be a serious risk in the dry season (January to July). Hunting is claimed locally not to be serious, but snare traps for terrestrial animals are common, and spear traps for pigs are so numerous that it is unsafe to leave any path in the area. Collection of firewood, rattan and bamboo was probably increasing with the population.

Conservation status A small area, mostly grassland, around Tusk Peak, is within Iglit-Baco National Park. Otherwise, apparently none of the area is protected, although some of it is afforded nominal protection as a "Catchment Forest". The most important areas are probably the remnant patches below $500 \mathrm{~m}$, which will be all but impossible to protect by statutory means. The Kalikasan Mindoro Foundation has started an ambitious education programme here, centred on species such as the Tamaraw and the Mindoro Imperial-pigeon, to make barangays and villages feel responsible for their remaining forests and to encourage more sustainable use.

Birds of particular conservation interest Mindoro Tarictic Hornbill, Black-hooded Coucal and Scarlet-collared Flowerpecker, with local reports of Mindoro Bleeding-heart and Philippine Cockatoo.

\section{Manamlay Lake}

Location A small area of hillside forest north of Sablayan in San Agustin barangay.

Forest description A small strip of lowland forest running for about $5 \mathrm{~km}$ along a ridge between 50 and $200 \mathrm{~m}$ altitude. Most forest was degraded with scattered secondary thickets, some perhaps naturally formed in landslides. A few patches of closed-canopy forest were present, especially on the steepest slopes; the east side had better forest.

Human use The slopes are too steep for kaingin but logging is a problem. A roost of flying foxes Pteropus species gives the reserve its name "the million bat

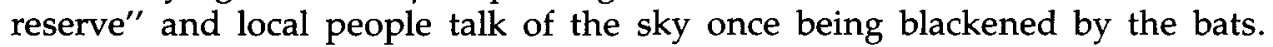
However a count indicated only 1,800 returning to roost in the morning. Hunting pressure on the bats has increased with local and export demand (V. Mitra verbally 1991).

Conservation status Part of the F. B. Harrison Game Reserve. There is a DENR bunkhouse and orchid garden; weekly visits were made by V. Mitra.

Birds of particular conservation interest Mindoro Tarictic Hornbill and Scarletcollared Flowerpecker, with local reports of Mindoro Bleeding-heart. 


\section{Sablayan Penal Colony}

Location About $30 \mathrm{~km}$ south-east of Sablayan, with forest on the south and east edge of the penal colony. This forest is contiguous with the patchy forests along the limestone ridge running north from Malpalon.

Forest description About 1,500 ha of lowland forest and a similar area of unvisited montane forest further east. The lowland forest is generally closed canopy with trees up to over $25 \mathrm{~m}$ tall and a relatively open forest floor. There are fewer limestone outcrops causing less disruption to the canopy than at Malpalon. Altitude ranges from 50 to $400 \mathrm{~m}$.

Human use There were minimal signs of human activity in the forest, with very few paths, just one trap and no logging seen. However, it was proposed to resettle several hundred refugees from the Mt Pinatubo disaster in Luzon to the area in 1992.

Conservation status The site may come within the F. B. Harrison Game Reserve. There is presumably some degree of protection afforded by the proximity of the penal colony.

Birds of particular conservation interest Mindoro Bleeding-heart, Mindoro Tarictic Hornbill, Black-hooded Coucal and Scarlet-collared Flowerpecker, with local reports of Philippine Cockatoo.

\section{Iglit-Baco National Park}

San Vicente and Malpalon are close to, but not within, Mt Iglit-Baco National Park, a site selected for special protection under the forthcoming Integrated Protected Areas Scheme (IPAS). Iglit-Baco National Park is mostly grassland, protected for tamaraw, but contains one area of forest close to Mt Iglit, a few other small patches, and an extensive block on steep slopes in the east Mindoro sector. These all appear to be high-altitude forest, probably on very steep slopes. The small pool featured in tourist literature on the park for its wild ducks had 74 Philippine Mallard Anas luzonica in December 1991. The park had five staff workers, with minimal technical support, to cover 75,544 ha of mountains.

A visit to these mountains on 26-29 December 1991 afforded good views of the geography and remaining forests of much of central-west Mindoro. The north-south ridge running past Malpalon and Sablayan had a scatter of degraded forest but most of the mountains and plateaus to the east were grassland or heavily degraded. Forest does exist in the north-west, which is contiguous with the Sablayan Penal Colony forest, and on the south and south-east slopes of Tusk Peak, extending south, possibly as closed-canopy lowland forest.

\section{Bongabong}

This forest was not visited but was seen from the road in March 1992. It is mapped on the satellite maps (SSC 1988) as mossy forest but appeared to be 
lowland forest when examined through binoculars from the road. Very few signs of human encroachment were visible and the forest extended down to about $100 \mathrm{~m}$ altitude. Gradients were gentle on the lower slopes and forest extended to the mountain peak at about $1,000 \mathrm{~m}$. There is thus the exciting possibility that this is a surviving undisturbed forest extending from lowland to mountain top.

\section{Conclusions}

The endemic birds of Mindoro can be split into montane species (Ducula mindorensis, Otus mindorensis) and lowland species (Gallicolumba platenae, Centropus steerii, Penelopides mindorensis and Dicaeum retrocinctum, with the possible addition of the unidentified Otus scops-owl). The montane species are restricted to small areas of forest and must have relatively low populations. Whilst it is highly advisable to implement conservation plans for these now, they are not in the same immediate danger as the lowland species.

Three of the four lowland species are severely threatened with extinction by deforestation and forest fragmentation, exacerbated by species-specific threats. Gallicolumba platenae is at risk from the large numbers of ground snares set for birds and small mammals, Centropus steerii may be displaced by $C$. viridis once forest is slightly degraded, and Penelopides mindorensis is a large frugivore, presumably needing relatively large tracts of forest for long-term survival.

Conservation of the montane species should concentrate in the Halcon range, aiming to minimize the local logging presently occurring along the lower border of the forest. Clearance of closed-canopy forest for kaingin may be a major problem elsewhere in this range and should be tackled alongside logging through alternative schemes of employment. The Philippine government has a scheme for upland development in Mindoro, aiming at the hill-dwelling Mangyan tribes. Mount Halcon, the third highest peak in the country, has the potential to be a tourist attraction to the large numbers of Western and Filipino tourists staying at the nearby town of Puerto Galera. Surveys of Iglit-Baco National Park are likely to reveal populations of the montane species, and forest conservation should be placed high on the agendas of both the national park and the tamaraw management programmes.

Lowland forest preservation needs immediate attention to prevent Mindoro going the way of Cebu, an island without any high mountains, which is virtually entirely deforested with the believed extinction of nine of its ten endemic bird taxa (Dickinson et al. 1991). DENR is charged with forest management, including enforcing logging bans and reforestation programmes. The three endemic birds discussed here are, however, in need of immediate action, coordinated by an international conservation organization. This should be targeted initially in central-west Mindoro with further field surveys to identify whether forest remnants in the far south and elsewhere in the west of Mindoro support viable populations of these and other threatened species.

The Kalikasan Mindoro Foundation is an environmental non-government organization founded in 1990 aiming to educate rural communities about the necessity for long-term planning and forest conservation. The foundation is 
concentrating on the Malpalon district, where it commands considerable local support.

\section{Further field surveys}

Based on the 1991 fieldwork and the forest-cover maps (SSC 1988), the following are in urgent need of surveying, in approximate order of priority: (1) Bongabong area as discussed above; (2) Central Occidental Mindoro (including Sablayan Penal Colony, south and south-east slopes of Tusk Peak and Poi Poi watershed); (3) South Mindoro (an extensive area of highly degraded forest, never visited by zoologists); (4) San Vicente (the 1991 fieldwork was highly incomplete, and other lowland species may well occur in this forest block); (5) Iglit-Baco National Park (a basic field survey, along the lines of the 1991 surveys and concentrating on any lowland forest, is essential for a balanced management plan for this park).

\section{Acknowledgements}

We are greatly indebted for help in the field from Vivencio Mitra (DENR, Sablayan), and the Chairman, Leonardo Gabutero, and volunteers, particularly Samson and Efraim Tejada, of the Kalikasan Mindoro Foundation. R.J.T. surveyed further sites on his own time and money, contributing all the above data from December 1991. The team owes a great debt to those people in the Philippines who worked hard smoothing out the various obstacles for us and for making our time so much more profitable. In particular, our gratitude goes to Carlo Custodio (Head, Wildlife Division, PAWB), Tim Fisher, Dr Pedro Gonzales (Head of Zoology, National Museum), The Haribon Foundation, Arne Jensen (ICBP-Philippines), Dr Frank Lambert (ICBP/IUCN) and Samuel Penafiel (Director, PAWB) in Manila; to Jardine Davis Inc. in Manila and Bacolod City; to Perla Magsalay (National Co-ordinator) and the staff of the AWB-Philippines on Cebu, Siquijor and Olango Island; and to the numerous DENR staff at PENRO and CENRO offices, particularly the local directors, who accommodated, advised and aided us. Among the latter, Mila Ebreo (Ilo Ilo, Panay), Dodo Balabin (Bacolod City), Chamberlin Babiera (Dumaguete City) and Vivencio Mitra (Sablayan, Mindoro) proved particularly knowledgeable and keen to help in the fieldwork - we wish them all success in the future.

Thanks also to our many advisors in the U.K. and U.S.A., in particular Gary Allport (ICBP), Dr Roger Cox, Finn Danielsen (Danish Ornithological Society), Edward Dickinson, Ian Hartley, Rod Hall, Professor Laurence Heaney, Dr Robert Kennedy and Dr William Oliver. Most of all, our appreciation goes to those who supported us financially. We are extremely grateful to Bio-science Supplies; British Airways-Assisting Nature Conservation; British Ecological Society; Mrs Bowie FLS; A. S. Butler Charitable Trust; Cambridge Expeditions Fund; Camlab Ltd; Cotton Trust; D. M. Charitable Trust; Douglas Heath Eves Charitable Trust; Mr and Mrs Dutson; Emmanuel College, Cambridge; Evans + Langford; Mr and Mrs T. M. Evans; Russell and Mary Foreman 1980 Charitable Trust; Gilchrist Educational Trust; Godinton Charitable Trust; Hawkins and Manwaring; H. E. Durham Fund; J. Saville Gordon Ltd; J. Wilson and Sons; Jardine Davis (Philippines) Inc; Jesus College, Cambridge; John West Foods Ltd; Laing's Charitable Trust; Memtek; New York Explorer's Club Youth Activity Fund; Oriental Bird Club; Rayne Foundation; Rob Thompson Memorial Fund; Robin Johnson Design Ltd; Royal Geographical Society (Barclay's Bank); Selwyn College, Cambridge; St John's College, Cambridge; Tate and Lyle; Walkers Shortbread; Wall Charitable Trust; Wellconstruct Trust; Mrs C. Willets; Mr 
G. S. Willets; Mr J. D. Willets; Wolverhampton Anglo-Netherlands Society; and to all of the generous Bird Race sponsors, especially the Carphone Warehouse.

\section{Appendix 1. Maximum day-totals for all resident forest species known from Mindoro.}

All resident forest species ever recorded from Mindoro are listed. Nomenclature and order follows Dickinson et al. (1991) with full species status given to the suggested splits in Scharringa and Inskipp (1991). The total number of bird-days logged by all observers in the 1991 expedition is given for all sites. This is clearly very dependent on the time spent in the field (see Table 2) and the physical structure of the forest. Species marked with * include call-only records. Birds marked with ? have not previously been recorded from Mindoro and are discussed in Evans et al. (in prep.). Philippine endemics are capitalized.

Site 1, Ilong; site 2, San Vicente; site 3, Malpalon (September); site 4, Malpalon (December); site 5, Manamlay Lake; Site 6, Sablayan Penal Colony.

\begin{tabular}{|c|c|c|c|c|c|c|}
\hline \multirow[b]{2}{*}{ Species } & \multicolumn{6}{|c|}{ Site } \\
\hline & 1 & 2 & 3 & 4 & 5 & 6 \\
\hline $\begin{array}{l}\text { Oriental Honeybuzzard Pernis ptilorhynchus } \\
\text { Barred Honeybuzzard } P \text {. celebensis }\end{array}$ & 1 & & 1 & & & \\
\hline White-bellied Sea-eagle Haliaeetus leucogaster & & & & & 1 & \\
\hline $\begin{array}{l}\text { PHILIPPINE SERPENT-EAGLE Spilornis holospilus } \\
\text { Besra Accipiter virgatus }{ }^{1} \\
\text { Crested Goshawk A. } \text { trivirgatus }^{1}\end{array}$ & 21 & 7 & 10 & 2 & 2 & 2 \\
\hline $\begin{array}{l}\text { Rufous-bellied Eagle Hieraaetus kienerii } \\
\text { Changeable Hawk-eagle Spizaetus cirrhatus }\end{array}$ & 4 & 1 & 2 & I & & \\
\hline PHILIPPINE HAWK-EAGLE $S$. philippensis & & & & & & 3 \\
\hline $\begin{array}{l}\text { PHILIPPINE FALCONET Microhierax erythrogenys } \\
\text { Tabon Scrubfowl Megapodius cumingii }\end{array}$ & & & 4 & & 1 & \\
\hline Red Junglefowl Gallus gallus & & 1 & & & & 11 \\
\hline WHITE-EARED BROWN-DOVE Phapitreron leucotis* & 8 & 52 & 19 & 3 & 1 & 1 \\
\hline Metallic Pigeon Columba vitiensis* & 7 & & & & & \\
\hline Philippine Cuckoo-dove Macropygia tenuirostris & 1 & 3 & 1 & & & 1 \\
\hline $\begin{array}{l}\text { Common Emerald-dove Chalcophaps indica } \\
\text { Nicobar Pigeon Caloenas nicobarica }\end{array}$ & & 1 & & & & \\
\hline MINDORO BLEEDING-HEART Gallicolumba platenae & & & & & & 2 \\
\hline Thick-billed Green-pigeon Treron curvirostra & & & & & & \\
\hline Pompadour Green-pigeon T. pompadora & & & 41 & & & \\
\hline $\begin{array}{l}\text { YELLOW-BREASTED FRUIT-DOVE Ptilinopus occipitalis* } \\
\text { BLACK-CHINNED FRUIT-DOVE } P \text {. leclancheri }\end{array}$ & 2 & 4 & & & & \\
\hline PINK-BELLIED IMPERIAL-PIGEON Ducula poliocephala* & 9 & 1 & & & & 1 \\
\hline MINDORO IMPERIAL-PIGEON D. mindorensis* & 22 & 3 & & & & \\
\hline Green Imperial-pigeon D. aenea & & & 26 & 16 & 15 & 17 \\
\hline SPOTTED IMPERIAL-PIGEON D. carola & & & & & & \\
\hline Pied Imperial-pigeon D. bicolor & & & & & & \\
\hline PHILIPPINE COCKATOO Cacatua haematuropygia & & & & & & \\
\hline $\begin{array}{l}\text { BLUE-HEADED RACQUET-TAILED PARROT Prioniturus } \\
\text { discurus* }\end{array}$ & 55 & 30 & 10 & 7 & & 1 \\
\hline BLUE-NAPED PARROT Tanygnathus lucionensis & & & & & & 2 \\
\hline $\begin{array}{l}\text { PHILIPPINE HANGING-PARROT Loriculus philippensis* } \\
\text { Hodgson's Hawk-cuckoo Cuculus fugax }\end{array}$ & & I & 18 & 11 & & 4 \\
\hline
\end{tabular}


Appendix 1. (cont.)

\begin{tabular}{llllllll}
\hline & \multicolumn{5}{c}{ Site } \\
\cline { 2 - 6 } Species & 1 & 2 & 3 & 4 & 5 \\
\hline
\end{tabular}

Plaintive Cuckoo Cacomantis merulinus

Rusty-breasted Cuckoo C. sepulcralis

Violet Cuckoo Chrysococcyx xanthorhynchus

Drongo Cuckoo Surniculus lugubris

Common Koel Eudynamys scolopacea

PHILIPPINE COUCAL Centropus viridis*

BLACK-HOODED COUCAL C. steerii*

MINDORO MOUNTAIN SCOPS-OWL Otus mindorensis*

PHILIPPINE HAWK-OWL Ninox philippensis

Brown Hawk-owl N. scutulata*

PHILIPPINE FROGMOUTH Batrachostomus septimus*

Great Eared-nightjar Eurostopodus macrotis

Philippine Nightjar Caprimulgus manillensis

Island Swiftlet Collocalia vanikorensis

PHILIPPINE SWIFTLET C. mearnsi ${ }^{2}$

PYGMY SWIFTLET $C$, troglodytes

White-bellied Swiftlet $C$. esculenta

Purple Needletail Hirundapus celebensis

Whiskered Tree-swift Hemiprocne comata*

INDIGO-BANDED KINGFISHER Ceyx cyanopectus

Oriental Kingfisher C. erithacus

MINDORO TARICTIC HORNBILL Penelopides mindorensis

Coppersmith Barbet Megalaima haemacephala

White-bellied Woodpecker Dryocopus javensis*

PHILIPPINE PYGMY WOODPECKER Dendrocopos maculatus*

Greater Flameback Chrysocolaptes lucidus

Red-bellied Pitta Pitta erythrogaster

Hooded Pitta P. sordida

Bar-bellied Cuckoo-shrike Coracina striata ${ }^{*}$

BLACK-BIBBED CICADABIRD C. mindanensis*

BLACK-AND-WHITE TRILLER Lalage melanoleuca

BALICASSIAO Dicrurus balicassius*

Slender-billed Crow Corvus enca

ELEGANT TIT Parus elegans*

PHILIPPINE BULBUL Hypsipetes philippinus*

White-browed Shortwing Brachypteryx montana*

ASHY GROUND-THRUSH Zoothera cinerea

$\begin{array}{rrrrrr}10 & 10 & 11 & 5 & 2 & 2 \\ 22 & 1 & 2 & & & 2 \\ 1 ? & & & & & \\ 1 ? & & 2 ? & & & \\ & 1 & 23 & & & \\ & 3 & & & & \\ + & + & + & + & + & + \\ - & - & - & - & - & - \\ 1 & & & 5 & & \\ + & + & + & + & + & + \\ 21 & & & & & \\ 7 & 3 & 7 & 5 & & 4\end{array}$

Sunda Ground-thrush Z andromedae

Island Thrush Turdus poliocephalus

Mountain Leaf-Warbler Phylloscopus trivirgatus

Snowy-browed Flycatcher Ficedula hyperythra*

Mangrove Blue Flycatcher Cyornis rufigastra

Mountain Verditer-flycatcher Eumyias panayensis

Black-naped Monarch Hypothymis azurea*

RUFOUS PARADISE-FLYCATCHER Terpsiphone cinnamomea

GREEN-BACKED WHISTLER Pachycephala albiventris*

MOUNTAIN SHRIKE Lanius validirostris

COLETO Sarcops calvus

Brown-throated Sunbird Nectarinia malacensis

Purple-throated Sunbird N. sperata

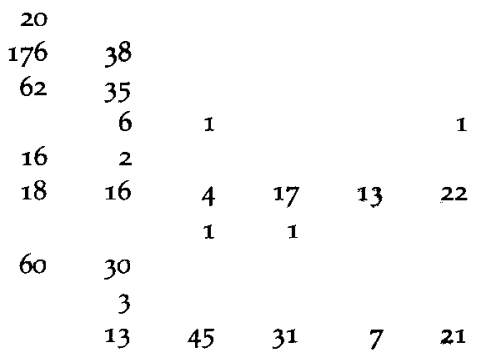


Appendix. (cont.)

\begin{tabular}{|c|c|c|c|c|c|c|}
\hline \multirow[b]{2}{*}{ Species } & \multicolumn{6}{|c|}{ Site } \\
\hline & 1 & 2 & 3 & 4 & 5 & 6 \\
\hline LOVELY SUNBIRD Aethopyga shelleyi & 22 & 5 & & & & 1 \\
\hline STRIPED FLOWERPECKER Dicaeum aeruginosum & & & & 1 & & \\
\hline BICOLOURED FLOWERPECKER D. bicolor* & 29 & 11 & 25 & 4 & & \\
\hline SCARLET-COLLARED FLOWERPECKER D. rectrocinctum* & 44 & 31 & & 6 & 1 & 3 \\
\hline Orange-bellied Flowerpecker $D$. trigonostigma & 1 & & & & & \\
\hline PYGMY FLOWERPECKER D. pygmaeum & 1 & 3 & 4 & & & \\
\hline Mountain White-eye Zosterops montanus & 22 & & & & & \\
\hline GOLDEN-YELLOW WHITE-EYE Z. nigrorum ${ }^{*}$ & 365 & 168 & & & & \\
\hline Tawny-breasted Parrotfinch Erythrura hyperythra & & & & & & \\
\hline
\end{tabular}

${ }^{1}$ These resident hawks Accipter spp. were probably overlooked because of confusion with migrant Chinese Goshawks $A$. soloensis and Japanese Sparrowhawks $A$. gularis.

${ }^{2}$ The larger swiftlets are dubiously identifiable in the field. The best field identification criterion is perhaps altitude, with Collocalia mearnsi occurring above $1,000 \mathrm{~m}$, but those at $1,300 \mathrm{~m}$ on Ilong looked more like $C$. vanikorensis.

\section{References}

Bourns, F. S. and Worcester, D. C. (1894) Preliminary notes on the birds and mammals collected on the Menage Scientific Expedition to the Philippine Islands. Occas. Pap. Minnesota Acad. Nat. Sci. 1: 1-64.

Brooks, T. M., Evans, T. D., Dutson, G. C. L., Anderson, G. Q. A., Asane, D. C., Timmins, R. J. and Toledo, A. G. (1992) The conservation status of the birds of Negros, Philippines. Bird Conserv. Internatn. 2: 273-300.

Collar, N. J. and Andrew, P. (1988) Birds to watch: the ICBP world checklist of threatened birds. Cambridge, U.K.: International Council for Bird Preservation (Techn. Publ. 8).

Cox, R. and Woodford, M. (1990) A technical evaluation of the Philippine Tamaraw Conservation Programme. Gland, Switzerland: IUCN (The World Conservation Union).

Dickinson, E. C., Kennedy, R. S. and Parkes, K. C. (1991) The birds of the Philippines. London: British Ornithologists' Union (Check-list 12).

DuPont, J. E. (1971) Philippine birds. Grenville, Delaware: Delaware Museum of Natural History.

Evans, T. D., Dutson, G. C. L., Brooks, T. M., Anderson, G. Q. A., Asane, D. C., Timmins, R. J. and Toledo, A. G. (in prep.) Cambridge Philippines Rainforest Project 1991. Final Report.

Goodwin, D. (1983) Pigeons and doves of the world. Ithaca, New York: Cornell University Press.

Johns, A. D. (1988) Effects of "selective" timber extraction on rainforest structure and composition and some consequences for frugivores and folivores. Biotropica 20: 31-37.

Kemp, A. C. (1988) The systematics and zoogeography of Oriental and Australasian hornbills (Aves: Bucerotidae). Bonn. zool. Beitr. 39: 315-345.

Lambert, F. R. (1992) The population size, distribution and ecology of the Philippine Cockatoo Cacatua haematuropygia. Unpublished report to IUCN/SSC and CITES Secretariat.

McClure, H. E. and Leelavit, P. (1972) Birds banded in Asia during the MAPS program, by locality, from 1963 through 1971. U.S. Army Research and Development Group, Far East. Report no. FE-315-7. 
McGregor, R. C. (1905) Birds from Mindoro and small adjacent islands. Bull. Bur. Govt. Labs., Manila 34: 5-67.

McGregor, R. C. (1906) Notes on birds collected in Mindoro and small adjacent offshore islands. Philippines J. Sci. 1: 697-704.

Ogilvie Grant (1896) On the birds of the Philippine Islands-Part VII. The highlands of Mindoro. Ibis (2)7: 457-477.

Rabor, D. S. (1959) The impact of deforestation on the birds of Cebu, Philippines, with new records for that island. Auk 76: 37-43.

Ripley, S. D. and Rabor, D. S. (1958) Notes on a collection of birds from Mindoro Island, Philippines. Peabody Mus. Nat. Hist. Yale Univ. Bull. 13: 1-83.

Scharringa, J. and Inskipp, T. P. (1991) A working supplement to duPont's Philippine birds. Oriental Bird Club Bull. 13: 13-19.

Sibley, C. G. and Monroe, B. L. (1990) Distribution and taxonomy of birds of the world. New Haven and London: Yale University Press.

SSC [Swedish Space Corporation] (1988) Mapping of the natural conditions of the Philippines. Final report.

White, C. M. N. and Bruce, M. D. (1986) The birds of Wallacea. London: British Ornithologists' Union (Check-list 7).

Whitehead, J. (1899) Field-notes on birds collected in the Philippine Islands in 1893-6.

Part III. Ibis 5(7): 381-399.

GUY C. L. DUTSON

Selwyn College, Cambridge $\mathrm{CB}_{3} 9 \mathrm{DQ}$, U.K.

TOM D. EVANS

ı1a Yeoman Lane, Bearsted, Maidstone, Kent ME14 4BX, U.K.

THOMAS M. BROOKS

Emmanuel College, Cambridge $\mathrm{CB}_{2}{ }_{3} A P, U . K$.

DESIDERIO C. ASANE

Asian Wetland Bureau, Unit 2, A. Sing Building, Duterte Street, Banawa, Cebu 6ooo, Philippines.

\section{ROBERT I. TIMMINS}

25 Cradley Road, Cradley Heath, Warley, West Midlands B64 6AG, U.K.

ANGELA TOLEDO

148-E Gorordo Avenue, Lahug, Cebu 6000, Philippines. 